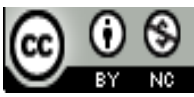 \\ Jurnal Terapan Manajemen dan Bisnis is licensed under \\ A Creative Commons Attribution-Non_Commercial 4.0 International License.
}

\title{
IMPROVEMENT STRATEGY OF COMPETITIVE ADVANTAGE AND MARKETING PERFORMANCE OF PUBLIC MARKET
}

\author{
Endah Budiarti \\ University of 17 August 1945 Surabaya, Surabaya, Indonesia \\ E-mail: endahbudiarti@untag-sby.ac.id
}

\begin{abstract}
The purpose of this research is to analyze and prove the influence of customer relationship management (CRM), service quality and entrepreneurship orientation to competitive advantage and marketing performance and to analyze and prove the influence of competitive advantage to marketing performance of the public market in East Java Province. The object of this research is the whole market unit of the public in East Java Province spread over 29 regencies and 9 cities in East Java Province amounting to 335 units of the public market. The unit of analysis in this research is a revitalized public market that is 67 public market in East Java Province. While the observation unit is a trader of a public market in East Java Province. The number of public market traders in the market that has been revitalized today is 25,000. In this research, researchers measured the marketing performance of the public market in East Java Province based on the perception of the trader, so the measure of marketing performance is perceptual. The sample used is 190 merchants. The number is spread across 67 units of the public market in East Java Province. The model to be used in this research is the model of causality or relationship. To test the proposed hypothesis, the analysis technique uses SEM (Structural Equation Modeling), with AMOS statistic software. The results of hypothesis testing: Customer relationship management, Quality of service and entrepreneurial orientation significantly influence the competitive advantage of the market public in East Java Province. Customer relationship management and service quality significantly influence the marketing performance of the public market in East Java Province, while the orientation of entrepreneurship has no significant effect on marketing performance of the public market in East Java Province. Competitive advantage influences the marketing performance of public market significantly in East Java Province.
\end{abstract}

Keywords: Customer relationship management (CRM), Service Quality, Entrepreneurship Orientation, Competitive Advantage, Marketing Performance, Public Market

\section{Introduction}

Along with the rapid development of the modern market, the existence of the public market gradually began to be threatened. The number of modern markets in Indonesia currently reaches 23,000 markets, whereas according to the Ikatan Pedagang Pasar Indonesia (IKAPPI), the total market of 9,950 markets in the last 4 years. Based on AC Nielsen's 2013 survey, the number of public's markets in Indonesia continues to decline. In 2007 the market of the public amounted to 13,550, declining to 13,450 in 2009, and in 2011 declined again to 
9,950 .

Comparison of the growth of the public market in Indonesia continues to decline. Growth for the public market minus 8.1 percent while the modern market grew 31.4 percent. Whereas the public's market has a small contribution to Revenue Original Regions. Besides, it also protects the interests of many public (Media Indonesia, 2016).

At this time the public's market is physically relatively worse getting abandoned by buyers. Buyers are beginning to shift in modern markets like hypermarkets, supermarkets, and others, which grow as a fulfillment of the lifestyles of modernity, where shopping needs to convert into leisure and entertainment activities. Coupled with the condition of the building is relatively much better, neat, comfortable, safe and economic situation of the price of goods offered by modern shopping centers is also cheaper than the public's market because of the distribution system better (Harmanto, 2007).

The policy of the government and local government in revitalizing the public's market is still more emphasis on the physical improvement of market buildings. It is rarely accompanied by institutional development such as developing the organization, managers and market builders of the public, including the development of market management systems and human resources involved as well as market traders.

Avoiding the failure of the public's market revitalization program, at the time of development planning it is necessary to think about the market capacity to be built in accordance with the number of existing traders, the possibility of increasing the number of existing traders, and the number and segment of consumers who will shop in those markets. Often there are many complaints from traders who have been trading since in the old market, when moving to a market that has been renovated kiosk sizes and stalls obtained to be reduced or smaller on the grounds that many new traders to be accommodated. This condition is the reason for traders to organize their merchandise to soar outside the stalls or kiosks soaring from the permitted limits. As a result, the gang/hallway in the market stalls becomes narrow and uncomfortable for buyers passing by in the market. The revitalization policy is also not so helpful for small economic actors because the implementation only emphasizes physical changes, such as the market must be clean, neat, comfortable, and not slums (Legowo, 2007).

The limitation of the managerial capability of the public's market manager affects the market condition in question, even this is one of the main causes of the attachment of the negative stigma that is now inherent in public's markets. Public's market development requires integrated effort, starting at the policy level up to the operational level. Development at the operational level is manifested in the form of foster management of market public and market traders as well as the development of street vendors and their environment. Further problems that also need to be coaching is the order of parking, pedestrian place arrangement, and culinary tourism area. Linkage with other areas is often overlooked, so the problem handling is partial, the result is less than the maximum because it cannot touch the root of the real problem.

The rapid growth of malls, supermarkets and minimarkets in Indonesia should be feasible to imitate and motivate the market of the public to improve the quality of physical and service management. The changes are expected to be attractive if the market is well managed, kept clean and trained traders, renovated without eliminating historical value so that public remain or even more interested in shopping in the market public. Until finally the traders in these folk markets still get a chance to improve their lives through economic activities that do, not vice versa, eliminated by the Mall or any other form of modern markets. 
Ideal conditions expected from the existence of the public market is a bargaining atmosphere and market model that gives a unique feel of shopping at the same time socializing and recreation. These nuances will be an attraction for tourists. The diversity of the public's market becomes an added value in an effort to attract tourists to come and visit the public's market. Development and development of the public market as part of tourism is also expected to open bigger business opportunities so that ultimately can improve the welfare of society. But the fact that there is, the diversity of the public market until now has not been utilized optimally as part and the carrying capacity for tourism (Suprihanto, 2016).

The public market as a government asset, for that need to make efforts enhancement marketing performance. This can be done by enhancing the competitiveness that can be created through the creation of more innovative products, improved service quality, appropriate marketing mix strategy, entrepreneurial orientation, and appropriate customer relationship management. When the marketing performance of the public market increases, it will have a positive impact on the survival of the public's market, so that the existence of the public's market can be maintained amid intense competition with the modern market.

This document is a template. An electronic copy can be downloaded from the conference website. For questions on paper guidelines, please contact the conference publications committee as indicated on the conference website. Information about final paper submission is available from the conference website.

The purpose of this research is to:

1. Analyzing and proving the influence of customer relationship management (CRM) to the competitive advantage of a public market in East Java Province.

2. Analyzing and proving the influence of service quality on the competitive advantage of a public market in East Java Province.

3. Analyze and prove the influence of entrepreneurship orientation on the competitive advantage of a public market in East Java Province.

4. Analyzing and proving the influence of customer relationship management (CRM) on marketing performance of the public market in East Java Province.

5. Analyzing and proving the influence of service quality to marketing performance of the public market in East Java Province.

6. Analyze and prove the influence of entrepreneurship orientation to marketing performance of the public market in East Java Province.

7. Analyzing and proving the influence of competitive advantage to marketing performance of the public market in East Java Province.

\section{Literature Review and Hypothesis \\ Customer Relationship Management (CRM)}

The main concept of Customer Relationship Management (CRM) is the formation of value. The goal is not to maximize profits, but to build long-term relationships with customers and improve customer satisfaction, increase customer loyalty by understanding customer needs and wants. Customer relationship management is the whole process of establishing and maintaining customer relationships conducted by the management of public market units managed by the public market in East Java Province

Measurement of customer relationship management, the researcher using the indicator in accordance with the opinion of Peppers and Rogers (2004) are as follows: Identify, that is public market identify customer and learn customer characteristics in detail, Differentiate, that distinguishes customer on the service according to their values and needs, Interact, that is interacting with the customer, this means building and maintaining two-way 
communication with the customer, Customize, that is adjusting the company's products and services in accordance with the value and needs of customers.

\section{Service Quality}

Service Quality focused on fulfilling the needs and desires of consumers. According to Wyckof in Muhtosim (2007: 93). that the quality of service is the level of excellence expected and control over the level of excellence to meet customer desires. Parasuraman (1990) in Muhtosim (2007: 80) said there are two main factors that affect the service quality that is expected service and perceived service if the services received in accordance with the expected quality of services perceived good or satisfactory. If the services received exceed customer expectations then the quality perceived ideal. The service quality reflects the comparison between the level of service delivered by the managers or management of the public's market unit of the public market in East Java Province compared to customer expectations.

Measurement of service quality using indicator in accordance with that proposed by Parasuraman, et al. in Tjiptono (2014) namely: Tangibles, meaning the appearance of market stand building and other supporting facilities provided market manager. Reliability means the ability of the officer or market manager to provide services to the trader. Responsiveness, meaning the alertness of the officers or market managers in providing services to traders or responding to problems faced by traders. Assurance, means knowledge, employee decency, and ability officers to generate trust and confidence of traders. Empathy means the willingness of officers or market managers to understand the difficulties of traders in each market unit.

\section{Entrepreneurship Orientation}

The entrepreneurship orientation plays an important role in improving business performance. Miller and Friesen (1982: 275) reveal that entrepreneurship orientation becomes an acceptable meaning to explain business performance. Meanwhile, according to Gosselin (2005: 169), that there is a significant relationship between the orientation of entrepreneurship established with the performance of the company. Lumpkin and Dess (1996: 231) defines an entrepreneurial orientation as a corporate benefits strategy to be able to compete more effectively within the same marketplace. The entrepreneurial orientation refers to the processes, practices, and decision-making undertaken by the management of the public's market unit of the public market in East Java Province, which has three aspects of entrepreneurship: always innovative, acting proactively and taking risks.

Measurement of entrepreneurship orientation, using indicators proposed by Lumpkin and Dess (1996) are: Always innovative, meaning innovations made by public market managers in providing services to traders; Proactively, meaning willingness and ability of officers or managers market to anticipate problems for traders; Dare to take risks, meaning the ability and courage of market managers to make decisions.

\section{Competitive Advantage}

Crown Dirgantoro (2001: 45) that, competitive advantage is the development of the value that the company can create for its buyers. Wahyudi (1996: 38) competitive advantage, is something that allows a company to gain higher profits compared to the average profit gained by competitors in the industry. The stronger the advantages are, the higher the profits the company will gain and vice versa. So it can be concluded competitive advantage cannot be understood by looking at the company as a whole. The competitive advantage comes from 
many different activities the company does in designing, producing, marketing, delivering, supporting its products. Each activity can support the company's relative cost position and create the basis for differentiation.

There are two basic competitive advantages, namely, cost advantage and differentiation. Competitive advantage is at the heart of every competitive strategy as has been expressed by Dirgantoro (2001: 61), competitive advantage evolves from the value that the company creates for its buyers that exceeds the cost of the company in creating it. Value is what buyers are willing to pay. To achieve cost advantage, a company must be ready to become a low-cost producer in its industry. Companies must have wide coverage and serve many segments, even operate within related industries. Sources of these advantages may include economic scale work, proprietary technology, access to raw materials and others. If a company can achieve and maintain a cost advantage, it will be a company with an average performance in the home industry able to control the price or near the industry average. In terms of differentiation, the company must be unique in its industry generally appreciated by the buyer, so the company is rewarded for its uniqueness. Differentiation is different for each industry and can generally be based on products, delivery systems, marketing approaches, and others. The competitive advantage is the ability of the Public's Market unit in East Java Province to achieve an economic profit above the profit that can be achieved by competitors in the market in the same industry and is the development of the value that can be created by the public market for its customers.

Measuring competitive advantage, researchers used indicators in accordance with the theory of Treacy and Wiersma (1997), with the consideration that the environmental situation developed very dynamically and the theory fits in a dynamic situation. The indicators are: Operational Excellence, meaning the cost efficiency and time of service provided by the market manager to the trader; Customer Intimacy, means the willingness and ability to understand the needs of the traders; Product Leadership, meaning the company creates superior and different products compared to competitors through innovation continuously.

\section{Marketing Performance}

Sales growth is a concept to measure the market performance of a product. Sales growth is a source of market share growth. Sales growth is used for all researchers as one of the market-forming performance variables. Market performance is part of marketing performance (Han et al., 1998: 76) and (Permadi, 1998: 81). Best in Manap (2016: 89), marketbased performance (market-based performance), as a measure of marketing performance refers to the external conditions and markets in which the company operates. For example by incorporating market growth factors, competitive pricing, product quality against competitors, and customer satisfaction. The inability of the marketing manager to justify the costs incurred in contributing to an increase in corporate profits due to the difficulty of designing indicators to measure marketing performance. Executives are considered failing to design indicators quantitatively to measure marketing performance as performance indicators in financial function (Clark, 2000: 57).

Measurement of performance in question is to prove that marketing has a quantitative contribution to the level of profitability that has been achieved company, making it easier for policymakers in monitoring marketing programs. Performance measurement company is not enough to only use the internal financial parameters such as sales revenue, net profit and return on investment but need to include external factors and markets as a reference in measuring company performance as well as profitability factors. 
Marketing performance is a measure of achievement obtained by market units public market in East Java Province from the activities of the marketing process as a whole. Measurement of marketing performance in this case perceptually. This means that in the measurement of marketing performance, researchers analyze based on customer perceptions. These researchers do base on new developments in the theory of performance appraisal results in marketing activities.

Measurement of marketing performance, researcher use indicator according to opinion Constantine et al. (2016) namely: Unit Sales, meaning the number of stand in each market unit sold; Perceived Quality, means the quality of services provided by market manager to the stand trader; Satisfaction, meaning the satisfaction of the public market traders for the services provided by market manager; Customer Retention, which is to identify the trader's desire to survive trading in a market run by the public's market in East Java Province or measuring how long a trader in the public's market.

\section{Hypothesis}

1. Customer relationship management (CRM) has a significant influence on the competitive advantage of a public market in East Java Province.

2. Service quality significantly influences to the competitive advantage of a public market in East Java Province.

3. Entrepreneurship orientation has a significant effect to competitive advantage of the public market in East Java Province.

4. Customer relationship management (CRM) has a significant influence on the marketing performance of the public market in East Java Province.

5. Service quality significantly influences to marketing performance of the public market in East Java Province.

6. Entrepreneurship orientation has a significant influence on the marketing performance of the public market in East Java Province.

7. Competitive advantage significantly influences to marketing performance of the public market in East Java Province.

\section{Research Methods}

The object of this research is the whole market unit of the public in East Java Province spread over 29 regencies and 9 cities in East Java Province amounting to 335 units of the public market of this $20 \%$ have been revitalized. So the unit of analysis (analysis unit) in this research is a revitalized public market that is 67 public market in East Java Province. While the observation unit is a trader or tenant of a community market stand in East Java Province. The number of public market traders in the market that has been revitalized today is 25,000 . In this research, researchers measured the marketing performance of the public market in East Java Province based on the perception of the trader or tenant stand, so the measure of marketing performance is perceptual. The sample used is 190 merchants. The number is spread across 67 units of the public market in East Java Province. The model to be used in this research is the model of causality or relationship. To test the proposed hypothesis, the analysis technique uses SEM (Structural Equation Modeling), with AMOS statistic software(Ferdinand, 2014).

\section{Results and Discussion}

The results of the calculations show that most of the goodness of fit criteria have not provided an index in accordance with the recommended. To further customize models built 
with data (empirical facts), modifications can be made. Modification of the model in SEM can be done through the help of modification index issued by AMOS software and also adapted to support the theory. The modified SEM model results are presented in Figure 1 below:

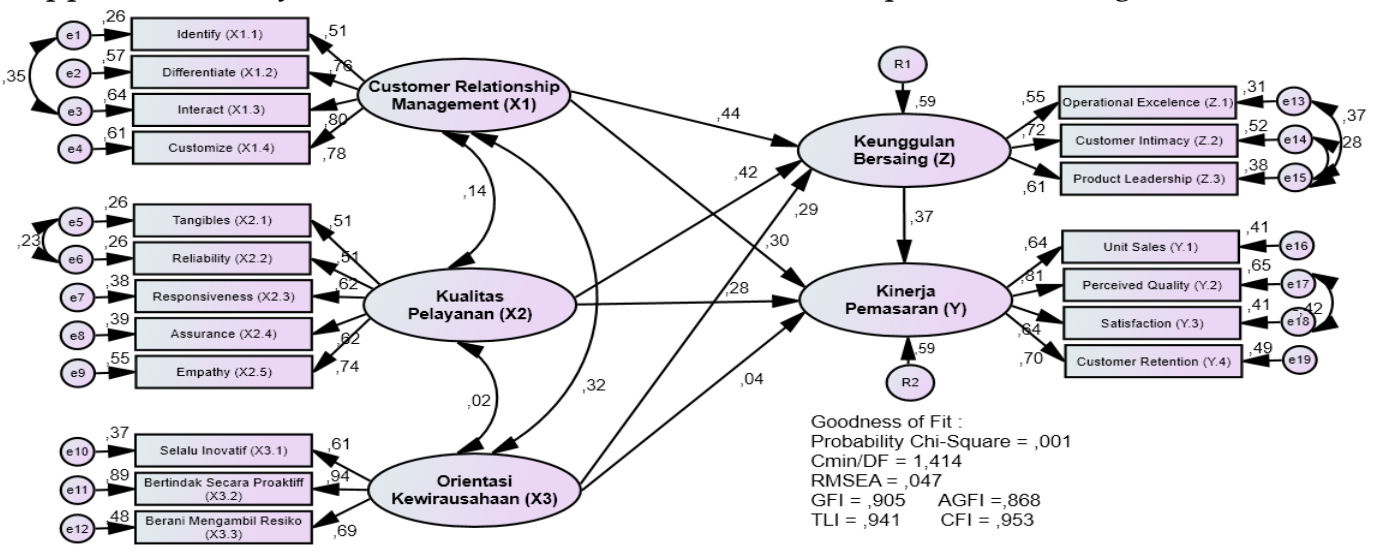

Fig. 1 Modification of SEM Model

The result of calculating the value of goodness of fit indexes produced by modification model is as follows:

Table 1: Value of Goodness of Fit and Cut off Value Modification Models

\begin{tabular}{lccc}
\hline \multicolumn{1}{c}{ Criteria } & Test Results Model & Critical Values & Description \\
\hline Probabilitas & 0,001 & $\geq 0,05$ & Marginal fit \\
X $^{2}$ Chi square & 1,414 & $\leq 2,00$ & Fit \\
Cmin/DF & 0,047 & $\leq 0,08$ & Fit \\
RMSEA & 0,905 & $\geq 0,90$ & Fit \\
GFI & 0,868 & $\geq 0,90$ & Marginal fit \\
AGFI & 0,941 & $\geq 0,90$ & Fit \\
TLI & 0,953 & $\geq 0,90$ & Fit \\
CFI & & & \\
\hline
\end{tabular}

Table 2: Hypothesis Testing Through Regression Weight Test

\begin{tabular}{|c|c|c|c|c|c|c|}
\hline \multicolumn{3}{|c|}{ Relationship of causality } & Std. & C.R. & $\underset{v a l u e}{P}$ & Description \\
\hline $\begin{array}{l}\text { Customer } \\
\text { Relationship } \\
\text { Management (X1) }\end{array}$ & $\rightarrow$ & $\begin{array}{c}\text { Competitive } \\
\text { Advantage (Z) }\end{array}$ & 0,438 & 3,698 & 0,000 & Significant \\
\hline $\begin{array}{l}\text { Quality of Service } \\
\text { (X2) }\end{array}$ & $\rightarrow$ & $\begin{array}{c}\text { Competitive } \\
\text { Advantage }(\mathrm{Z})\end{array}$ & 0,419 & 3,539 & 0,000 & Significant \\
\hline $\begin{array}{l}\text { Orientation of } \\
\text { Entrepreneurship (X3) }\end{array}$ & $\rightarrow$ & $\begin{array}{l}\text { Competitive } \\
\text { Advantage (Z) }\end{array}$ & 0,294 & 3,219 & 0,001 & Significant \\
\hline $\begin{array}{l}\text { Customer } \\
\text { Relationship } \\
\text { Management }(X 1)\end{array}$ & $\rightarrow$ & $\begin{array}{l}\text { Marketing } \\
\text { Performance } \\
\text { (Y) }\end{array}$ & 0,302 & 2,499 & 0,012 & Significant \\
\hline $\begin{array}{l}\text { Quality of Service } \\
\text { (X2) }\end{array}$ & $\rightarrow$ & $\begin{array}{l}\text { Marketing } \\
\text { Performance } \\
\text { (Y) }\end{array}$ & 0,280 & 2,368 & 0,018 & Significant \\
\hline $\begin{array}{l}\text { Orientation of } \\
\text { Entrepreneurship (X3) }\end{array}$ & $\rightarrow$ & $\begin{array}{l}\text { Marketing } \\
\text { Performance } \\
\text { (Y) }\end{array}$ & 0,038 & 0,438 & 0,661 & $\begin{array}{c}\text { Not } \\
\text { Significant }\end{array}$ \\
\hline
\end{tabular}




\begin{tabular}{|c|c|c|c|c|c|c|}
\hline \multicolumn{3}{|c|}{ Relationship of causality } & \multirow{2}{*}{$\begin{array}{c}\begin{array}{c}\text { Std. } \\
\text { Estimate }\end{array} \\
\\
0,375\end{array}$} & \multirow{2}{*}{$\begin{array}{l}\text { C.R. } \\
2,007\end{array}$} & \multirow{2}{*}{$\begin{array}{c}\begin{array}{c}P \\
\text { value }\end{array} \\
0,045\end{array}$} & \multirow{2}{*}{$\begin{array}{l}\text { Description } \\
\text { Significant }\end{array}$} \\
\hline $\begin{array}{l}\text { Competitive } \\
\text { Advantage (Z) }\end{array}$ & $\rightarrow$ & $\begin{array}{l}\text { Marketing } \\
\text { Performance } \\
\text { (Y) }\end{array}$ & & & & \\
\hline
\end{tabular}

\section{Conclusion}

1. The result of variable parameter estimation of customer relationship management to competitive advantage showed the significant result with CR value 3,698 (bigger than 1,96 ) and p-value equal to 0.000 (less than $5 \%$ ). The resulting coefficient of influence is 0.438 (positive), meaning that the higher customer relationship management then the competitive advantage is also higher. Thus, the first hypothesis stating that customer relationship management has a significant effect on the advantages of competing traders or renters at the market booth in East Java Province, acceptable (H1 accepted). This indicates that for a trader special attention from market managers is important in establishing good relations, for example, the form of attention is the opportunity to hold meetings to improve market hygiene, market management to meet the desire of traders to perform social/religious activities and allow traders to creativity peddle merchandise. Things like this are able to increase the satisfaction for the market traders of the public.

2. The result of parameter estimation of service quality variable to competitive advantage also showed the significant result with CR value 3,539 (greater than 1,96) and p-value equal to 0.000 (less than 5\%). The resulting coefficient of influence is 0.419 (positive), meaning the higher the quality of service then the competitive advantage is also higher. Thus, the second hypothesis which states that the quality of service has a significant effect on the advantages of competing traders or tenant booths in the public's market in East Java Province, also acceptable ( $\mathbf{H} 2$ accepted). The quality of services provided by the managers or management of the public's market unit in East Java Province is implemented through Tangible, Reliability, Responsiveness, Assurance, and Empathy which have an impact on increasing the competitive advantage of the public market in East Java Province. Tangible is implemented with the stand building made in accordance with the standard size of a particular space, plot or block is made with visitor access road in all directions. The vehicle parking of traders is available wide enough to meet the needs of the merchant's facilities and infrastructure. The element of Reliability is manifested by the management of the public's market unit in East Java Province with lighting and air circulation is available enough, Standing arrangements already based on the type of merchandise. Responsiveness by public market unit managers in East Java Province with market managers consistently serving traders friendly; Market officers consistently implement counter-measures fires are good. All ownership documents tenants in this market are listed in the market office. All data on payment of tenants fees/other fees are recorded in the administration of the market office. Market managers consistently oversee the scales used for trading (orderly measuring); Responsible market officials with market hygiene and order issues, Market officers are responsive to market security problems.

3. The result of parameter estimation of entrepreneurship orientation variable to competitive advantage also shows the significant result with CR value 3,219 (bigger than 1,96 ) and p-value equal to 0,001 (less than 5\%). The resulting coefficient of effect is 0.294 (positive), meaning that the higher the entrepreneurship orientation, the higher the competitive advantage. Thus, the third hypothesis stating that the entrepreneurial orientation has a significant effect on the advantages of competing traders or renters of 
booths in the public's market in East Java Province, also acceptable (H3 accepted). The entrepreneurship orientation is the process, practice and decision making done by the management of public market unit in East Java Province. Three aspects of the approach, that is innovative, acting proactively and dare to take risks. Innovative that is explored through market executives innovate to facilitate efficient ways of communicating with traders. Market managers make breakthroughs by facilitating landfills and waste treatment methods. Market managers innovating the way of online retribution and marketers always striving to promote well/intensive. This has an effect on increasing competitive advantage in the public market in East Java Province.

4. The result of variable parameter estimation of customer relationship management to marketing performance showed the significant result with CR value 2,499 (greater than $1,96)$ and p-value equal to 0,012 (less than $5 \%$ ). The resulting coefficient of influence is 0.302 (positive), meaning that the higher customer relationship management hence a real impact on the improvement of marketing performance. Thus, the fourth hypothesis stating that customer relationship management has a significant effect on the marketing performance of traders or rent tenants at the public's market in East Java Province, also acceptable (H4 accepted). This illustrates that the identify, differentiate, interact, and customize activities that have been carried out by market managers have not been able to influence the satisfaction and retention of traders in the public's market in East Java Province. Satisfaction and customer retention as part of a measure of marketplace marketing performance. The satisfaction and retention of the public's market traders can increase as the competitive advantage of the public market increases. The competitive advantage of this research is measured by operational excellence, customer intimacy, and product leadership. Means that when the cost of arranging rent/buy cheap market booth, the process of managing various activities in the market can be done quickly and cheaply, market officers strive to maintain closeness with traders; market managers pay attention to the needs of infrastructure facilities traders; managers can anticipate the occurrence of things that can make problems for traders; managers often inquire about the development of trading activities to traders; market levies are relatively cheap compared to other markets; then the market marketing performance of the public will increase.

5. The result of parameter estimation of service quality variable to marketing performance also shows the significant result with $C R$ value 2,368 (greater than 1,96 ) and p-value equal to 0.000 (less than $5 \%$ ). The resulting coefficient of effect is 0.280 (positive), meaning the higher the quality of service then the marketing performance is also high. Thus, the fifth hypothesis which states that the service quality has a significant effect on the marketing performance of traders or renters of booths in the public's market in East Java Province, also acceptable (H5 accepted). Service Quality provided by management or management of a market unit implemented through Tangibles, Reliability, Responsiveness, Empathy able to improve marketing performance of the public market in East Java Province. The tangibles of the public's market in the city of Surabaya is run by making the stand building is made in accordance with the standard size of a certain space, plot or block is made with visitor access road in all directions, Vehicle parking of traders is widely available so as to fulfill the needs of merchant facilities and infrastructure .

6. The result of parameter estimation of entrepreneurship orientation variable to marketing performance showed the insignificant result with CR value 0,438 (smaller than 1,96) and p-value equal to 0,661 (greater than 5\%). The resulting coefficient of effect is only 0.038 , meaning that the higher the orientation of entrepreneurship does not have a real impact on the improvement of marketing performance. Thus, the sixth hypothesis stating that 
the entrepreneurial orientation has a significant effect on the marketing performance of traders or renters of booths in the public's market in East Java Province, rejected (H6 rejected). The entrepreneurship orientation is the process, practice and decision making done by the management of public market unit in East Java Province, with three aspects of the approach, that is innovative, acting proactively and dare to take risks. Innovative that is translated through market executives innovates to facilitate efficient ways of communicating with merchants. Market managers make breakthroughs by facilitating landfills and waste treatment methods. Market executives innovate the way of levy payment online and market management always try to do promotion well / intensive cannot influence to marketing performance of the public market in East Java Province.

7. The result of parameter estimation of competitive advantage variable to marketing performance showed the significant result with CR value of 2,007 (greater than 1,96) and the p-value was 0,045 (less than $5 \%$ ). The resulting coefficient of influence is 0.375 (positive), meaning the higher the competitive advantage then the marketing performance is also high. Thus, the seventh hypothesis which states that the competitive advantage has a significant effect on the marketing performance of the trader or the booth tenant in the public's market in East Java Province is acceptable (H7 accepted). Competitive advantage is the ability of units public market in East Java Province to achieve economic benefits are elaborated through the cheap cost of the process of leasing the market; the ease of traders in communicating with market officers; the easy process of management; market officials strive to maintain closeness with the traders; managers pay attention to the needs of facilities and infrastructure of traders can improve marketing performance in the public market in East Java province with the number of stands and market stalls sold, not a lot of open space in this unused market, smooth service to traders about the process of arranging the lease/purchase of stands, good cleaning service and garbage handling, the service about parking system, good quality, the satisfaction of the merchant to the facilities provided in this market, as according to the trader's expectation.

\section{References:}

Clark, B. H. (2000). Managerial Perception of Marketing Performance: Efficiency, Adaptability, Effectiveness, and Satisfaction. Journal of Strategic Marketing, 8(1), 325.

Constantine, S. Katsikeas, Neil A. Morgan-Leonidas C. Leonidou \& G. Tomas M. Hult. (2016). Assessing Performance Outcomes in Marketing. Journal Marketing, 8, 1-20.

Dirgantoro, Crown. (2001). Manajemen Strategik: Konsep,Kasus, dan Implementasi, Jakarta: Grasindo.

Ferdinand, Augusty. (2014). Structure Equation Modelling Dalam Penelitian Manajemen. Semarang: Undip.

Gosselin, Maurice. (2005). An Empirical Study of Performance Measurement in Manufacturing Firm. International Journal of Productivity and Performance Management, 54(5/6), 419-437.

Han et al. (1998). Market Orientation, Innovativeness, Product Innovation and Performance in Small Firm. Journal of Small Bussiness Management, 42(2).

Harmanto. (2007). http://harmanto,blog.detik.com/index.php/archieves/61. (Accessed on July 4, 2017).

Legowo, Martinus, FX., Sri Sadewo \& M. Jacky. (2007). Pedagang dan Revitalisasi Pasar Tradisional di Surabaya: Studi Kasus Pada Pasar Wonokromo dan Pasar Tambah 
Rejo Surabaya. http://journal.unair.ac.id/fiter.pdf/11-martinus-pdf

Lumpkin, G.T., \& Dess, G.G. (1996). Clarifying the Entrepreneurial Orientation Construct and Linking it to Performance. Academy of Management Review, 21(3), 135-172.

Manap, Abdul. (2016). Revolusi Manajemen Pemasaran. Jakarta: Mitra Wacana Media.

Media Indonesia. (2016). Menerapkan SNI Pasar Rakyat. http://mediaindonesia.com/news.read/41656/menerapkan-sni-pasar-rakyat/2016. (Accessed on July 15, 2017).

Miller, D., \& P. Friesen. (1982). Innovation in Conservative and Entrepreneurial Firms: Two Models of Strategic Momentum. Strategic Management Journal,3, 1-25.

Muhtosim, Arief. (2007). Pemasaran Jasa dan Kualitas Pelayanan. Malang: Bayumedia Publishing.

Peppers, D., \& Rogers, M. (2004). Managing Customer Relationship: A Strategic Framework. Jersey: John Wiley and Sons.

Permadi, M. F.,(1998). Pengembangan Konsep Kinerja Pasar. Jurnal Ekonomi dan Bisnis Indonesia, 13(3), 70-79.

Suprihanto, John., Nugroho, Henry Prihanto., \& Syaiffudin, Agus Amin. (2016). Revitalisasi Pasar Tradisional sebagai Objek Destinasi Wisata Studi di Kabupaten Sleman Yogvakarta. dalam artikel seminar. Yogyakarta.

Tjiptono, Fandy. (2014). Pemasaran Jasa - Prinsip, Penerapan dan Penelitian. Yogyakarta: Andi.

Treacy, M. \& Wiersma, F. (1997). The Discipline of Market Leader: Choose Your Customer, Narrow your Focus, DominateYour Market. Massachusetts: Addison-Wesley.

Wahyudi, Agustine Sri. (1996). Manajemen Strategik:Pengantar Proses Berfikir Strategik. Jakarta: Binarupa Aksara. 